\title{
Mitigating mountain hazards in Austria - legislation, risk transfer, and awareness building
}

\author{
M. Holub ${ }^{1,2}$ and S. Fuchs ${ }^{2}$ \\ ${ }^{1}$ RiskConsult, Sicherheits- \& Risiko-Managementberatung GmbH, Vienna, Austria \\ ${ }^{2}$ Institute of Mountain Risk Engineering, University of Natural Resources and Applied Life Sciences, Vienna, Austria
}

Received: 4 November 2008 - Revised: 12 March 2009 - Accepted: 23 March 2009 - Published: 2 April 2009

\begin{abstract}
Embedded in the overall concept of integral risk management, mitigating mountain hazards is pillared by land use regulations, risk transfer, and information. In this paper aspects on legislation related to natural hazards in Austria are summarised, with a particular focus on spatial planning activities and hazard mapping, and possible adaptations focussing on enhanced resilience are outlined. Furthermore, the system of risk transfer is discussed, highlighting the importance of creating incentives for risk-aware behaviour, above all with respect to individual precaution and insurance solutions. Therefore, the issue of creating awareness through information is essential, which is presented subsequently. The study results in recommendations of how administrative units on different federal and local levels could increase the enforcement of regulations related to the minimisation of natural hazard risk. Moreover, the nexus to risk transfer mechanisms is provided, focusing on the current compensation system in Austria and some possible adjustments in order to provide economic incentives for (private) investments in mitigation measures, i.e. local structural protection. These incentives should be supported by delivering information on hazard and risk target-oriented to any stakeholder involved. Therefore, coping strategies have to be adjusted and the interaction between prevention and precaution has to be highlighted. The paper closes with recommendations of how these efforts could be achieved, with a particular focus on the situation in the Republic of Austria.
\end{abstract}

\section{Introduction}

In Austria, strategies to prevent or to reduce the effects of natural hazards in areas of settlements and economic

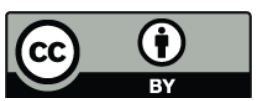

Correspondence to: M. Holub

(m.holub@riskconsult.at) activities trace back in the mediaeval times; official authorities were only founded in 1884 (Länger, 2003) based on a first legal regulation (Österreichisch-Ungarische Monarchie, 1884). In the second half of the 19th and the early 20th century protection against natural hazards was mainly organised by implementing permanent measures in the upper parts of the catchments to retain solids from erosion and in the release areas of avalanches. These measures were supplemented by silvicultural efforts to afforest high altitudes. Since the $1950 \mathrm{~s}$ such conventional mitigation concepts - which aimed at decreasing both, the intensity and the frequency of events were increasingly complemented by more sophisticated technical mitigation measures. Until the 1970s, mitigation concepts mainly aimed at the deflection of hazard processes into areas not used for settlements.

In the Republic of Austria conventional mitigation of natural hazards institutionally originates from the 1890 s when the French system of forest-technical torrent and avalanche control was adopted. Watershed management measures, forestbiological and soil bio-engineering measures as well as technical measures (construction material: timber and stone masonry) had been implemented. Thus, conventional mitigation concepts only consider technical structures within the catchment, along the channel system or track and in the deposition area. According to the approach of disposition management (reducing the probability of occurrence of natural hazards) and event management (interfering the transport process of the hazard itself), a wide range of technical measures is applicable.

Conventional technical measures against mountain hazards, such as deflection and retention walls as well as torrential barriers, are not only very cost-intensive in construction, moreover, because of a limited lifetime and therefore an increasing complexity of maintenance in high-mountain regions, the feasibility of technical structures is restricted due to a scarceness of financial resources provided by responsible authorities. If maintenance is neglected mitigation measures

Published by Copernicus Publications on behalf of the European Geosciences Union. 
will become ineffective and can even increase the catastrophic potential of natural hazards. Since conventional technical measures do neither guarantee reliability nor complete safety, a residual risk of damage to buildings, infrastructure and harm to people remains.

Experiences from last years suggested that values at risk and spatial planning should be increasingly considered within the framework of natural hazard risk reduction (Fuchs et al., 2005; Zischg et al., 2005a, b; Kano-nier, 2006; Keiler et al., 2006). To meet this goal, integral risk management strategies seem to be a valuable instrument to reduce the susceptibility of buildings and infrastructure to natural hazards and to develop strategies for a strengthened resistance (Fuchs et al., 2007a), above all by means of local protection measures.

Besides conventional technical mitigation measures, structural precaution is achieved by an adapted construction design and the appropriate use of an object. Structural precaution is the main application domain for local structural measures, since the individual vulnerability of buildings can be fundamentally decreased by strengthening e.g. brick walls with reinforced concrete components, and/or the adopted interior design of the different rooms according to occupancy time and hazard potential (Holub and Hübl, 2008).

The principles of planning and implementation of local structural measures to reduce vulnerability against natural hazards are neither highly sophisticated nor very innovative (Fuchs, 2009). However, the overall framework of dealing with mountain hazards in Austria does not explicitly take into account such principles.

Firstly, the legislation related to natural hazards is diverse due to the federal structure of the Republic of Austria. Several articles at federal level are supplemented by various regulations on the level of the federal states (Länder level) and even below at community level, in particular with respect to land use planning. Secondly, different strategies to mitigate and thus compensate the effects of mountain hazards exist in Austria. These strategies, above all the governmental disaster fund and private insurance solutions, are neither particularly coordinated with respect to risk minimisation nor do they create considerable incentives for individuals to prevent losses. Thirdly, risk awareness is not very prevalent throughout the country due to an information deficit related to the general occurrence of mountain hazards and mitigation strategies and concepts to avoid losses.

In this paper aspects on legislation related to natural hazards in Austria are summarised, with a particular focus on spatial planning activities and hazard mapping, and possible adaptations focussing on enhanced resilience are outlined. Furthermore, the system of risk transfer is discussed, highlighting the importance of creating incentives for risk-aware behaviour, above all with respect to individual precaution and insurance solutions. Therefore, the issue of creating awareness through information is essential, which is presented subsequently.

\section{Legislation}

In the Austrian legislation, multiple regulations with respect to natural hazards exist (Fig. 1). However, no uniform and consistent text of law with respect to the protection from the effects arising from natural hazards is given. In contrast, implications governed by public law are large in number and multifaceted, and include articles in the Austrian Forest Act, the Austrian Hydrography Act and the Disaster Fund Act at federal level as well as laws regulating spatial planning and land use planning on the Länder level, just to name the most prominent. Further articles with implications for natural hazard risk management are covered by individual articles of the federal traffic law and the law related to disaster management. On the Länder level, articles of the laws related to fire brigades and of the policies for disaster aid include individual regulations with respect to natural hazards. Subsequently, multiple agreements between the federal state and the Länder exist, above all regulating financial issues with respect to early warning systems, mutual rights related to alerts, and several articles on financial compensation. Hence, due to the strong federal character of the Republic of Austria, legislation and execution of issues arising from dealing with the effects of mountain hazards are assigned to different federal, Länder, and local authorities depending on their respective jurisdiction and competence (Fig. 1). Accordingly, these authorities get also individually active with respect to the administration of the private sector, e.g., concerning aspects of prevention and loss adjustment.

Despite these multiple responsibilities at different governmental levels, the most important and fundamental laws - the Austrian Forest Act and the associated decree related to hazard mapping - will be addressed in the following sections.

\subsection{Hazard mapping and spatial planning}

In Austria, the methodology for delimiting hazard zones is regulated by a national legal act (Republik Österreich, 1975) and an associated decree (Republik Österreich, 1976). The implementation of these regulations is assigned to the Federal Ministry of Agriculture, Forestry, Environment and Water Management (BMLFUW) and administrated by the governmental departments of the Austrian Service for Torrent and Avalanche Control (WLV) in the upper parts of the catchments and the Federal Water Engineering Administration in the lower parts of the catchments. The Austrian Forest Act ( $\$ 8 \mathrm{~b}$ ) of 1975 prescribes the delimitation of hazard zones in catchment areas susceptible to natural hazards such as torrential floods or avalanches (Forest Act $§ 99$ ) and areas reserved for mitigation measures. In $\S 11$, the compilation of hazard maps and the involvement of communes and population are regularised. The contents and designs of these maps are specified by a decree associated to the Forest Act (Republik Österreich, 1976). According to §5(2) of this Decree on Hazard Zoning, all available data and information 


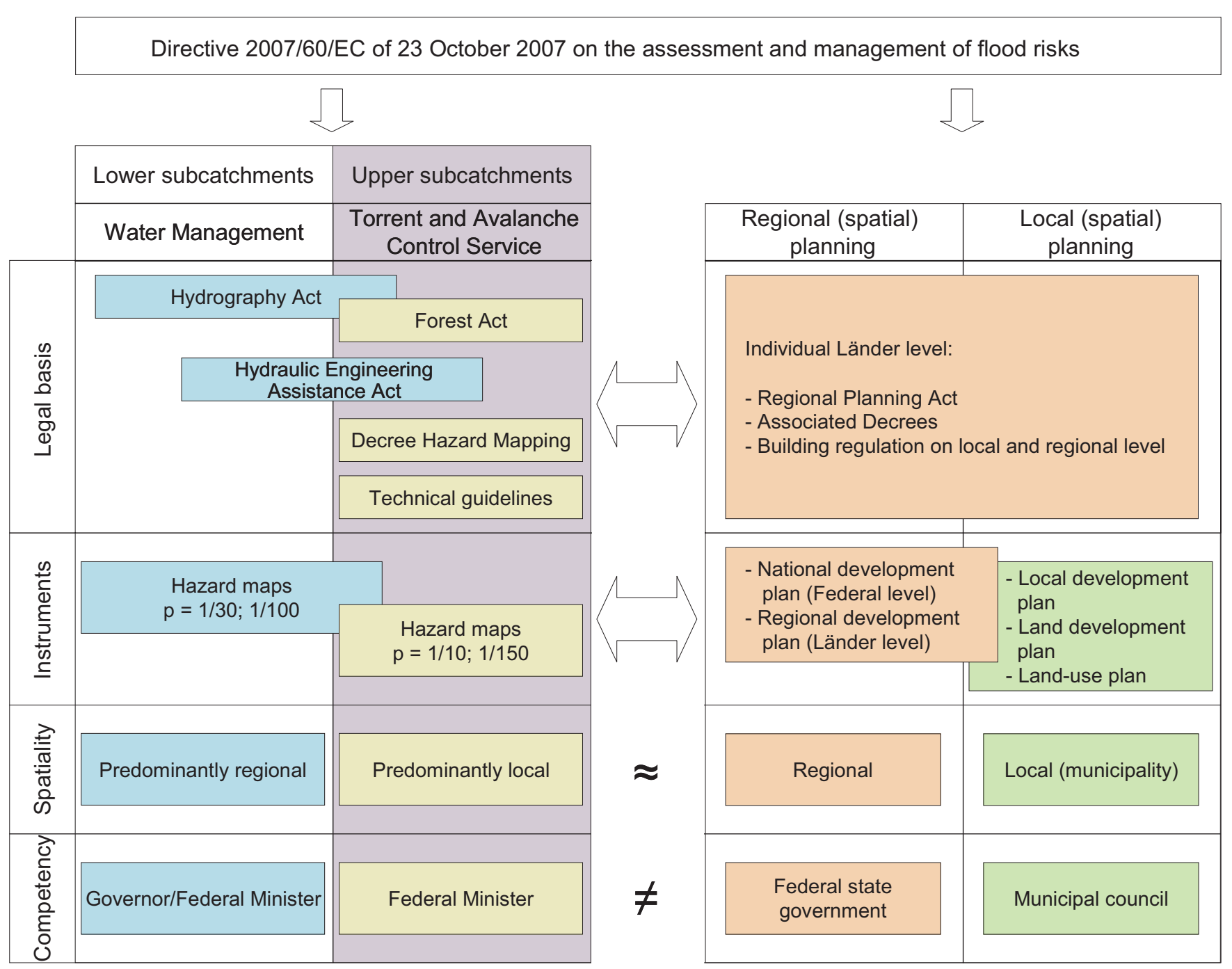

Fig. 1. Structure of the planning system related to mountain hazards in Austria (modified from ÖROK, 2005).

on natural hazards as well as interactions between individual hazard processes have to be considered during the compilation of hazard maps. Furthermore, interferences with the human environment, such as infrastructure facilities and settlements have to be taken into account. Hazard maps are usually based on the area of an individual community, and should be compiled in a reproducible manner to allow for validation during the approval process by the Federal Ministry of Agriculture, Forestry, Environment and Water Management. Hazard maps are based on a design event with a return period of 1 in 150 years, and an event occurring more frequent with a return period of 1 in 10 years (Republik Österreich, 1976). In $\S 6$ of the Decree on Hazard Zoning, the criteria for delimitation of hazard zones is prescribed. According to these prescriptions, red hazard zones indicate those areas where the permanent utilisation for settlement and traffic purposes is not possible or only possible with extraordinary efforts for mitigation measures. Yellow hazard zones indicate those are as where a permanent utilisation for settlement and traffic purposes is impaired by hazard processes. Furthermore, specific other areas have to be displayed in the hazard map: blue colours mark areas to be provided for future mitigation measures, above all silvicultural measures, brown colours indicate areas affected by landslides and rockfall, and purple colours indicate areas that can be used as protection due to their natural properties, such as protection forests or natural retention basins.

From a legal point of view, the hazard map does not bind land use planners directly in their decisions since the delimitation of hazard zones is not statutory regulation in accordance with the Austrian Superior Administrative Court (VwGH 27.03.1995, 91/10/0090, Hattenberger, 2006; Kanonier, 2006). As a consequence, hazard maps are not normative acts resulting in certain external effects or actions but they are classified as an opinion of experts providing a forecast for prospective developments of natural hazards 
effects. Accordingly, if the protection against natural hazards is intended to be fundamental for the decision-making of an administrative body, any conflicts arising between these decisions and the content of hazard maps have to be at least technically justified. Approaching this issue differently, administrative responsibility will be neglected considerably if the content of hazard maps is not taken into account accordingly in any governmental action. Hence, hazard maps are not legally binding for spatial planning purpose unless there is particular reference in the individual spatial planning law of the individual Länder, e.g. the Tyrolean Act on Spatial Planning explicitly addresses the protection of areas suitable for building activities against the adverse effects of natural hazards (Amt der Tiroler Landesregierung, $2006 \S 1$ Abs. 2 lit. d). Nevertheless, the content of hazard maps is internally binding for any administrative body in terms of an order, in particular for the governmental departments of the Austrian Service for Torrent and Avalanche Control (WLV) and the Federal Water Engineering Administration (Hattenberger, 2006). Furthermore, due to European and international law, i.e. the Alpine Convention (CIPRA, 1998) and the European Flood Risk Directive (Commission of the European Communities, 2007), areas endangered by natural hazards have to be depicted accordingly in order to exclude them from further development activities.

Regional planning and regional development are a matter of the Austrian Länder and related legal regulation is within the individual Länder responsibility. Hence, for the regional as well as local planning level multiple regulations with respect to land utilisation, land use planning and building development exist. Considering areas endangered by natural hazard processes the traditional way to direct development activities in areas not exposed is an overall major principle but also a major task for local administrative bodies responsible, since areas for development are relatively scarce. However, as outlined by Kanonier (2006) the principle of Länder legislation providing higher-order environmental policy guidelines and establishing mandatory regulations to support municipalities for executions on a local level is no longer traceable in the present spatial planning reality. Although regional planning and the subordinated land development plan as main administrative tool are statutory, an implementation on the local level is not necessarily deducible. Because of the particular interests of stakeholders involved, higher-order regulations might be solved with respect to individual local needs differently. Furthermore, recently introduced participative approaches are gaining increasingly importance in order to provoke cooperation with parties affected. These affected parties regularly experienced restrictions for development of existing building land due to defined hazard zones (as a consequence of updated hazard information), including prohibition of development within a defined period in time and within a certain location. Consequently, stakeholders on the local level might disesteem Länder requirements, which will be mirrored directly on the local political decision level.
An additional problem is the different horizon of spatial planning activities (5-10 years on the local level, 30-50 years on the regional level) and the hazard mapping process (1020 years). In this regard, the implementation of the European Flood Risk Directive will contribute to a harmonisation since according to Art. 4, preliminary flood risk maps have to be compiled until December 2011, and according to Art. 6 the Member Countries are obliged to prepare area-wide flood risk maps until December 2013. Furthermore, these maps have to be regularly updated during a six-year interval (Commission of the European Communities, 2007).

Until now, a considerable diversity of interpretation is detectable with respect to the inclusion of natural hazard prevention in the spatial planning process in different Länder in Austria. Since regulations related to regional planning and development include - besides the prevention against the adverse effects of natural hazards - several other aims, multiple interests in utilisation and possibilities of development are confronted with the need to protect settlements and infrastructure against possible losses resulting from hazard processes. Hence, a conflict of objectives is inevitable. In order to implement a minimum standard of protection against natural hazards, building regulation is a purposeful tool to convert prevention into action.

\subsection{Building regulation}

To implement long-term planning policies and related spatial planning aims into practice, multiple measures and instruments on different administrative levels are possible. Two major principles to avoid an increasing risk potential exist, the avoidance to extend development land into areas affected by natural hazards, and the prescription of certain building regulations and structural measures, such as local structural protection. Thereby, spatial planning activities are not able to lower existing values exposed in already built-up areas. In contrast, by limiting re-zoning at local governmental level, constructional development activities of plots located in endangered areas are adjusted in order to not increase values at risk exposed considerably. These mandatory restrictions in development on the local level are part of a hierarchical multi-stepped system within the regional planning and land use planning legislation as well as in the building laws at the Länder level and below in the municipalities (Kanonier, 2006). The regional development plan is therefore an appropriate tool to prescribe in a top-down approach certain regulations to individual municipalities on the local level. Hence, a minimum requirement is the depiction of hazard zones in these plans, whereas the level of detail varies considerably between individual Länder in Austria. While in the Federal State of Vorarlberg areas of certain relevance for the planning process have only to be visualised, it is mandatory in the Federal State of Salzburg to identify areas necessary for flood runoff and flood retention as well as areas indicated 
in hazard maps (Amt der Salzburger Landesregierung, 2004, Slbg ROG § 16 Abs. 2 lit. c; Amt der Vorarlberger Landesregierung, 1996, Vlbg RplG 1996 § 12 Abs. 5).

However, the communal administrative opportunity for judgement might be considerable, above all with respect to possible exceptions applicable to guarantee the economic development of a certain region. The extent of consequences arising from natural hazard processes is directly influenced by the legal execution in the respective community or region.

The historical shift of a traditionally agricultural society to a service industry- and leisure-oriented society is mirrored by socioeconomic development in mountain environments and foreland regions. This shift is reflected by an increasing use of those areas for settlement, industry, and recreation. Due to an increasing concentration of tangible and intangible assets and to an increasing number of persons exposed to natural processes, there is an emerging need for the consideration of risk in land use development. Long-term analyses of risk evaluating these changes provided a general idea about the development of assets in endangered areas. Regarding the long-term development in values at risk, a significant increase could be proven for the period between 1950 and 2000 in the Eastern Alps (Fuchs et al., 2005; Keiler et al., 2006).

This development strengthens the need for due diligence processes in spatial planning and land development, above all with respect to building regulations to be increasingly implemented in planning processes on the local level. Even if the consideration of natural hazard processes is already implemented in the planning procedure on different administrative levels under the responsibility of multiple authorities, there is a particular need to enact the mandatory authorisation of planned constructions in areas influenced by natural hazard risk. The designation of development land requires the general adequacy of the plots for the intended use; consequently, building bans should be enacted for those areas that are due to their natural conditions not suitable for such purpose. However, such building bans are rarely implemented in practice and are often only applicable to red hazard zones (Kanonier, 2006). Moreover, the legally prescription of protection in areas less endangered by natural processes also seems to be not very successful in practice. Examples include in particular situations when the planned constructions intend not to increase the values at risk considerably, or if the developed land will not be extended into areas with a significantly increased hazard potential. Among others, corresponding regulations can be found in the Federal State of Upper Austria and in the Federal State of Tyrol (Amt der oberösterreichischen Landesregierung, $2004 \S 21$ Abs. 1a lit. 2; Amt der Tiroler Landesregierung, $2006 \S 37$ Abs. 2 lit. b).

As outlined above, the prescription of local structural protection is a promising principle in order to minimise risk. Considering different mass movement processes and their impacts on the built environment, multiple solutions for the protection of new buildings and the upgrade of existing inventory exist (Holub and Hübl, 2008). Recent studies related to torrential hazards in Austria (Fuchs et al., 2007a) and Switzerland (Romang et al., 2003) suggested a considerable decrease in vulnerability, if local structural protection is implemented. However, until now risk-minimising effects of local structural measures have only rarely been quantified so far (Holub and Fuchs, 2008), presumably since mandatory legal regulations are almost missing therefore. Only the Federal State of Vorarlberg explicitly addresses the possibility to prescribe legal requirements for local structural measures, if economically reasonable and technically feasible, in the respective land use planning act (Amt der Vorarlberger Landesregierung, 1996, Vlbg RplG 1996 § 13 Abs. 2 lit. a).

\subsection{Future needs}

Land use planning activities such as hazard maps are based on the concept of recurrence intervals of hazard processes. Since the hazard potential and thus the delimitation of hazard zones is subject to temporal changes, the resulting coping strategies in order to minimise risk have to be variable. From the point of view of spatial planning dealing with such changes is of particular difficulty since the required stability of the law restricts short-term modifications in land use planning regulations to a minimum. In particular building bans and re-zoning of already permitted land development activities remain an unsolved task since once enacted and approved by the regulatory authority additional prescriptions or prohibitions could hardly be accomplished. Hence, the overlap between hazard areas and areas used for settlement purpose and economic activities increasingly provokes conflicts of interest that need to be addressed in natural hazard management.

Nevertheless, due diligence as legal obligation resulting in usage limitations and prohibitions executed during the individual construction process is inevitable, in particular with respect to the prescription of local structural protection. Ongoing inspections by the respective authorities, associated certification and final approval of work should be legally prescribed. Furthermore, the increased consideration of hazard maps already during the constructing permit procedures as well as the mandatory involvement of the respective authority (Austrian Torrent and Avalanche Control Service) during the entire process seems promising with respect to create more disaster-resilient communities.

Apart from the cost-efficiency (Holub and Fuchs, 2008), local structural protection is a serious and promising approach in mitigating natural hazards with respect to legal requirements in accordance with local planning regulations. This is of particular relevance considering the fact that building regulations other than local structural measures are hardly to be implemented ex post. Due to the overall principle of reliance on legal acts, planning decisions affirmed in the past have to be persistent over a certain period in time.

With respect to natural hazard management, legal regulations related to land use decisions are accompanied by the principle of governmental loss compensation in Austria. 


\section{Loss compensation in Austria - the disaster fund}

As a basic principle, different strategies are applicable as instruments to mitigate the effects of natural hazards. Within the scope of integral risk management, their individual benefits and possible weaknesses have to be balanced against each other. Hence, mitigation measures can be classified according to the idea of integral risk management by their ability to raise individual awareness and to facilitate the willingness of people affected becoming proactive and investing private money. In order to achieve this goal, mitigating natural hazards is pillared by regulatory instruments as well as other management strategies in dependence on their applicability as preventive (modification of the natural hazard process and/or damage potential) or subsequent reactive measures (maintenance, see Table 1). With respect to the latter emphasis is placed on the compensation of resulted damages, e.g. by shifting the costs for compensation to an insurance pool or by disbursing public expenditures or governmental aids. In Austria, such governmental aids play a major role in loss compensation since natural hazards are not subject to compulsory insurance. Apart from the inclusion of losses resulting from hail, pressure due to snow load, rock fall and sliding processes in an optional storm damage insurance, no standardised product is currently available on the national insurance market. Moreover, the terms of business of this storm damage insurance explicitly exclude coverage of damage due to avalanches, floods and inundation, debris flows, earthquakes and similar extraordinary natural events (Schieferer, 2006; Weiß, 2008).

\subsection{Background}

According to the constitution of the Republic of Austria, losses resulting from natural hazards do not fall under the national jurisdiction. Thus, any responsibility for potential aids to repair damage to assets of individuals, companies and legal entities resulting from natural hazards generally is assigned to the Länder (Fuchs et al., 2007b).

Nevertheless, assistance for compensation was required on the federal level in 1950/51 due to the avalanche disasters that occurred in large areas of the Austrian Alps. Subsequently, the Republic of Austria issued a special law for the financial support of and governmental aid for persons harmed by avalanches. Further major hazard events required additional specifications of this law until the floods of 1965/66 necessitated the establishment of a permanent so-called disaster fund.

The Federal Act related to the Disaster Fund of 1966 (Republik Österreich, 1966) provided the legal basis for the provision of national resources for

- preventive actions to construct and maintain torrent and avalanche control measures, and
- financial support for the Länder to enable them to compensate individuals and private enterprises for losses due to natural hazards in Austria.

To provide financing of the disaster fund, tied surcharges were put on income taxes, wage taxes, taxes on capital yields, and corporate taxes. After being subject to several amendments, the legal act from 1966 was revised by the so-called Federal Act related to the Disaster Fund of 1996 (Republik Österreich, 1996 ). This law is still in force in the prevailing form. The budget of the disaster fund originates from a defined percentage (since 1996: 1.1\%) of the federal share on the income taxes, taxes on capital yield, and corporate taxes, which amounts to approximately $7 €$ for private households and $30 €$ for business entities per year (Vetters and Prettenthaler, 2004). Financial means which are not spent in a respective year are subject to a reserve. In accordance with the Austrian Court of Audit, the prescribed maximum reserves of the disaster fund is limited to 29 million $€$ (Republik Österreich, 1996). This regulation resulted in a redistribution of additional reserves to other budget items in years with below-average incurrence of losses, which is one of the major problems of the strain on liquidity of the disaster fund if above-average losses occur.

Within the Federal Act related to the Disaster Fund of 1996 (Republik Österreich, 1996) the allocation of resources is legally prescribed. A considerable share of the budget has to be provided for the prevention of damage resulting from floods and avalanches, as well as the funding of passive flood mitigation measures. Further provisions include the survey of water quality, the funding of early warning devices, and the subsidising of the crop hail insurance in Austria. The prevention of flood and avalanche losses not only includes direct financial aids, but also the measurements undertaken by respective institutions under public law, i.e. the Austrian Torrent and Avalanche Control Service. Further financial resources have to be spent for remedial actions to be undertaken for losses resulting from natural hazards that occurred at properties and assets of local public authorities, and the acquisition of equipment for the locally-based voluntary fire brigades.

A major budgetary item, also from the point of public perception, is the regular support of the Länder by the disaster fund in providing subsidies for disaster compensation to individuals and legal entities affected by natural hazards. Losses of private households and companies due to natural hazards are compensated to a certain degree by the disaster fund. The disaster fund, respectively the Republic of Austria, subsidises the Länder up to $60 \%$ of that financial aid that was paid out by the Länder in order to support parties aggrieved by natural hazards. By these compensations, affected parties can receive an average indemnity up to a total of $20-30 \%$ of the overall amount of losses suffered.

The disaster fund also provides financial assistance to any level of government. At the local and Länder, damages to 
infrastructure facilities are subsidised, and on the federal level damages to waterways and motorways are compensated by $50 \%$ of the overall amount of loss.

Since the competence of compensating losses that incurred due to natural hazards is allocated at the Länder level, the Länder are not only responsible for assessing damages but also for the loss payment. In general, after damage has been recorded by a locally-based expert commission, compensations are paid out by the respective federal province directly to the people affected. Thereby, financial aids of the Länder are reduced by the share received as compensation paid out by optional hazard insurance companies. However, there is neither any enforceable legal right for financial assistance, nor a certain level of guaranteed financial assistance resulting from the disaster fund act. The Federal Ministry of Finance administrates the resources of the disaster fund.

\subsection{Future needs}

Societal and political decisions about mitigation measures concerning natural hazards are generally based on a multiplicity of interests due to the variety of parties involved. One major characteristic of mitigation measures is that the private sector does not supply them in a sufficiently great enough quantity given the potential economic benefits to society, therefore mitigation measures have characteristics of public goods or common (pool) resources (Fuchs and McAlpin, 2005). In the theory of public goods it is assumed that individuals are aware of their preferences. However, consumers might not always be aware of their preferences for protection measures, which can be partly attributed to free supply, passive consumption - and governmental subsidies for disaster compensation to individuals and legal entities affected by natural hazards. This somehow insufficient starting position, tracing back to the non-excludability and non-rivalry in consumption, requires a centralised coordination of the government. Hence, until now, market failure is the normative rationale for governmental intervention in order to mitigate natural hazards, and the provision of protection against natural hazards is commonly regarded as a governmental duty. However, direct governmental interventions do not offer any explicit incentive for individuals to react risk minimising and voluntarily to a threat, and to subsequently provide prevention measures on an individual basis (which in case of local structural protection would be characterised by excludability and rivalness). Limited public resources and steadily increasing financial losses from natural hazards demand a more efficient allocation of public expenditures (Raschky and Weck-Hannemann, 2007), which might be - until now solely achievable by raising risk awareness and consequently encouraging private expenditures in local structural protection measures.

It is widely accepted that living in areas endangered by natural hazards belongs to the category of involuntary risks even if this is only partly true since citizens and other people
Table 1. Possible preventive and reactive measures to mitigate natural hazards.

\begin{tabular}{ll}
\hline Preventive measures & $\begin{array}{l}\text { Subsequent/ } \\
\text { reactive measures }\end{array}$ \\
\hline $\begin{array}{l}\text { Administration (e.g., evacuation) } \\
\text { Planning tools (e.g., hazard mapping, } \\
\text { land use planning, building codes) }\end{array}$ & Disaster fund \\
$\begin{array}{l}\text { Technical structures } \\
\text { Forestal-biological measures } \\
\text { (e.g., protection forest) }\end{array}$ & Liability \\
\hline
\end{tabular}

affected in principle could choose between different alternative locations for living and economic activities. Hence, losses from natural hazards not only can be ascribed to the geographic location itself (hazards-of-place model of vulnerability, Cutter, 1996; Cutter et al., 2003), but are also a result from individual choices and preferences. Accordingly, voluntariness and awareness will become influencing factors in the near future with respect to the ongoing discussion on a possible implementation of a compulsory hazard insurance system in Austria (Schieferer, 2006; Holub and Hübl, 2008). If these ideas will become reality, according to the principle that the party responsible is liable for the damages a certain contribution will be demanded from those people living in endangered areas. From the economic point of view, and thus from the viewpoint of the disaster fund as a governmental constitution, this instrument of liability represents a solution-orientated and efficient incentive in order to provoke risk-reducing behaviour, and in order to create disasterresilient communities.

However, until now, the disaster fund has to be considered as the only available compulsory nation-wide solution in Austria, showing the following characteristics:

- Independently from the exposure to natural hazards, premiums are levied on a legal basis as a certain percentage of the federal share on the income taxes, taxes on capital yield, and corporate taxes.

- These premiums have to be paid by every citizen and business entity, independently from the individual exposure to certain hazards.

- There is no legal claim to a compensation of losses.

- Due to divergent legal regulations in the Länder, the conditions of damage compensation are considerably different within the Republic of Austria, leading to social injustice if large areas are affected by hazardous events (e.g., during the 2002 and 2005 flood events).

- Preventive measures are not considered in terms of a smaller premium rate; in contrast, private precaution in terms of individually contracted insurances will reduce the compensation paid out from the disaster fund. 
Balance of the disaster fund

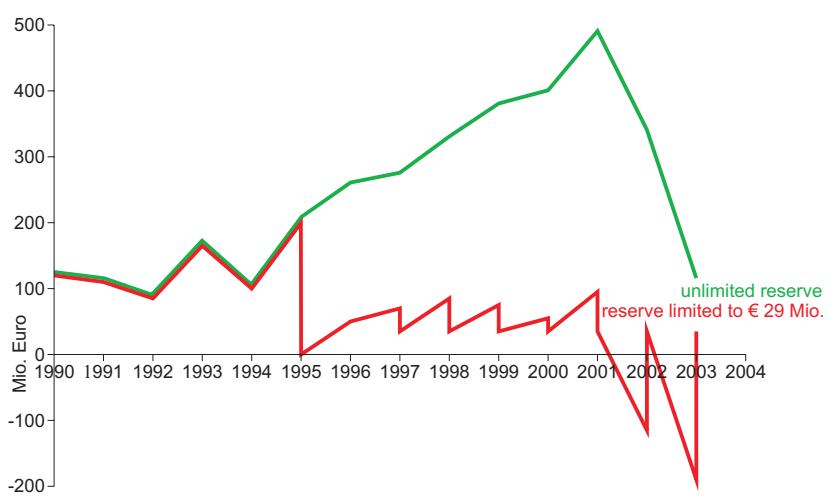

Fig. 2. Balance of the disaster fund with and without capped budget (modified from Prettenthaler and Vetters, 2005).

As laid down in the Federal Act related to the Disaster Fund of 1996 (Republik Österreich, 1996) and outlined above, the capped resources amount to 29 million $€$ per year. Consequently, accumulated resources above this amount are regularly removed from the fund, and alternatively used within the national budget of Austria. The result of this procedure is shown in Fig. 2 by the red line, indicating the continuous annual withdrawal of reserves. The green line, alternatively, indicates the theoretical development of the accumulated reserves if the fund was not fixed upwards by 29 million $€$. In 2002 and 2003, major compensations were paid out by the budget of the disaster fund, consequently, additional resources had to be made available by the Republic of Austria in order to cover the occurring financial gap (red line). Alternatively, if the fund was not fixed, the accumulated budget would have been sufficient to compensate these losses (green line).

In Fig. 3, the overall expenditures of the disaster fund are indicated for the period 1991-2003. The budget used for loss compensation (white bars) is shows considerable fluctuations, while the other expenditures incurred according to the Federal Act related to the Disaster Fund of 1996 (Republik Österreich, 1996) are relatively stable (grey bars). Therefore, measures of the budgetary risk management are required to supplement the budgeting of the reserves, arguing for an independent organisation of the loss adjustment, e.g., by splitting-off this sector according to the procedure in actuarial business (Prettenthaler et al., 2005) to allow for independent hedging transactions. Since so far, risk-averse behaviour is not taken into account during loss compensation, a decoupled organisation of the loss-compensating share would allow for the initiation of measures that create considerable incentives to implement mitigation measures, i.e., privately financed local structural protection systems. In contrast, by the present system, negative incentives for households and business entities are provided, in particular since
Loss compensation vs. overall expenditures

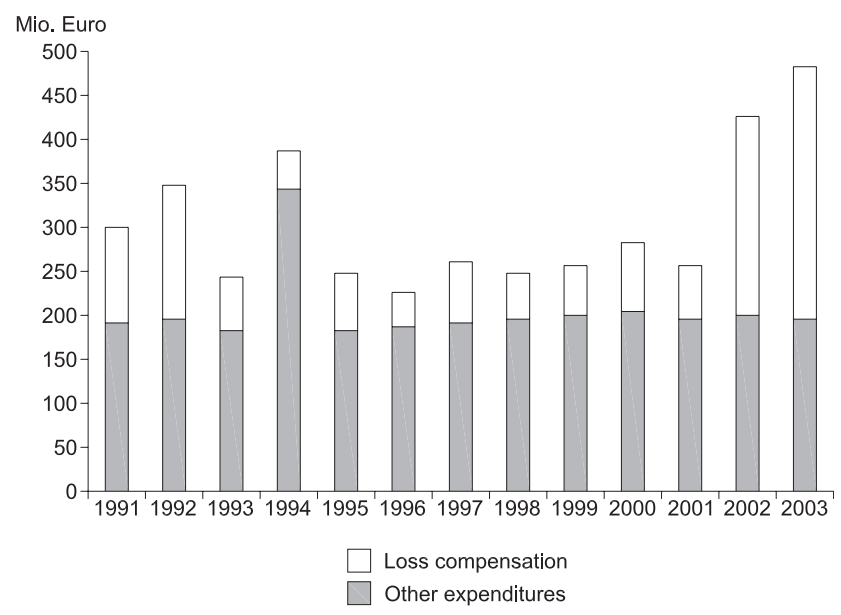

Fig. 3. Disaster Fund: expenses for loss adjustment versus total expenditures 1991-2003 (modified from Prettenthaler and Vetters, 2005).

private insurance indemnities are subtracted before governmental compensation is paid out.

Among others, Prettenthaler and Vetters (2005), Schieferer (2006), and Weiß (2008) suggested adjustments of the current system of loss compensation in Austria, which include

- a splitting of different financial sectors of the disaster fund, i.e. the prevention and loss adjustment into different budgetary units, a loss adjustment pool and a pooled prevention funds;

- an outsourcing of the loss adjustment pool under supervision of the Austrian Financial Market Authority including the possibility of

- a mandatory coverage extension for property insurers in Austria by a combined natural hazard package with basic premiums charged commensurate with the risk in order to avoid averse selection;

- a fixed distribution of the related premium income achieved with a share of $30 \%$ for the insurer and $70 \%$ for the disaster fund; and accordingly

- a proportionate loss adjustment with a share of $30 \%$ from the insurers' own funds and $70 \%$ from the disaster fund.

- Insurers only accept risks if these are in line with the capacity limits they have set. Capacity is the maximum amount of coverage that could be offered by an insurer over a given period. Hence, a stop-loss coverage by the disaster fund should be introduced if the annual compensations paid out by the insurers exceed the 
sevenfold annual premiums. Thereby, the possibility of cession should remain unaffected.

By these adjustments of the current system of loss compensation, incentives to implement local structural protection can be set with respect to an efficient risk management facing future challenges emerging from natural hazards in Austria. Thereby, a diversified portfolio balance is essential, which will only be possible by an adoption of the current national system of disaster aid to the items outlined above.

\section{Risk transfer in Austria}

Shifting risk from one party to another is the basic principle of risk transfer, and a key issue in (economic) risk management. Insurance as a form of risk management is primarily used to hedge against the risk of a contingent loss. Insurance is defined as the equitable transfer of the risk of a loss, from one entity to another, in exchange for a premium, and can be thought of a guaranteed small loss to prevent a large loss. As outlined by Schieferer (2006) and Weiß (2008), insurance coverage against losses resulting from natural hazards is available in Austria since the mid-1950s, in particular with respect to losses occurring due to windstorm (airflow with velocities $>60 \mathrm{~km} / \mathrm{h}$ ), hail, snow load (application of force due to naturally accumulated static snow packs), rockfall, and landslides (down slope movement of soil and rock masses along a subsurface shear plane). It is only since the mid-1990s that other natural hazard processes may be included in insurance contracts, namely by individually extended coverage since in general they are excluded of liability (Weiß, 2008).

\subsection{Background}

Besides the system of the disaster fund outlined in the previous section, private or business entities may also insure against the losses incurring from natural hazards with private insurance companies. However, until now, private insurance companies only provide policies with very limited coverage for damage arising from natural hazards. According to the Austrian Underwriting Association, most insurance companies cover for damages to private buildings and households up to a sum between $3700 €$ and $15000 €$ per contract, while only few insurers compensate up to $50 \%$ of the insured sum (Gruber, 2008). These relatively small contractual amounts covered are effected without any risk assessment on the insurers' side, and therefore do neither mirror commensurate premiums nor incentivise individuals to a risk-aware behaviour with respect to e.g. an private investment in preventive measures. Business entities are granted more flexible contract conditions than private households, in particular since they have access to combined policies (specifically "all risk policies"), hence, higher coverage against losses resulting from natural hazards is available.
On request, some contractors offer higher coverage based on appropriate premium rates; therefore, detailed risk assessments are regularly undertaken (Schieferer, 2006). The associated extended cover is carried out either up to a fixed maximum sum amounting to $20000 €$ per insurance policy, or up to $25-50 \%$ of the building value. However, even these policies cannot cover for all types of hazardous events and obviously exclude extraordinary, i.e. extreme, events.

Since natural hazard insurance is not compulsory in Austria so far, the main obstacle private insurers have to deal with is adverse selection, which is the adverse impact on an insurer when risks are selected that have a higher probability of loss than that contemplated by the applicable insurance rate. With respect to natural hazards, adverse selection occurs since only those persons and business entities being located in endangered areas tend to contract insurances. In order to encounter adverse selection, insurance companies try to reduce exposure to large claims either by limiting coverage or by raising premiums.

Apart from the effect of adverse selection, the market penetration of insurance policies is relatively low due to the mechanism of loss compensation by the disaster fund. To benefit from these compensations, people do need neither to pay written premiums nor do they have to contribute to the available funds otherwise - a strong incentive for more risky behaviour. Thus, the issue of third-party intervention, i.e., governmental funding, turned out to be a crucial aspect for the Austrian insurance market (e.g., Froot, 2002). Furthermore, and this is presumably the second reason for low market penetration, in most of the Länder the compensations paid out by the disaster fund are shortened by (private) insurance compensations. Hence, risk-aware people underwriting private natural hazard insurances are de facto worse off than less aware people not taking precaution actions, which leads again to decreasing demand in natural hazard insurance policies in Austria.

\subsection{Future needs}

Mountain hazards are defined from an engineering point of view as a function of the probability of occurrence of a specific scenario and the corresponding losses (Varnes, 1984) or - more generally and thus including perspectives from social sciences - the result of human economic activity in mountain regions (Fuchs et al., 2007b; Raschky, 2008). Focussing on the latter, both theoretical and empirical research had shown that the market for risk-transfer tends to work imperfectly or even fail completely with respect to natural disasters (Kunreuther and Pauly, 2004). Adverse selection and moral hazard, occurring when individuals behave in ways to satisfy themselves, but their behaviour comes at the detriment of others because they do not bear the full cost, can only partly explain these market imperfections (Jaffee and Russell, 2003). Kunreuther (2000) defined situations of distorted demand and insufficient supply on the 
market for natural hazard insurance as the disaster syndrome: individuals tend to underinsure because of the underestimation of risk of low-probability high loss events, and the expected financial relief by governmental compensation or private donation, the latter being described as charity hazard by Raschky and Weck-Hannemann (2007). This market failure led to different forms of government intervention in the market for disaster insurance (e.g., Ungern-Sternberg, 2004), i.e., the disaster fund in Austria. In addition to an inefficient amount of insurance coverage, financial assistance from the government does rarely meet the needs of the disaster victims and therefore results in an inefficient allocation of public resources, a phenomenon that was extensively observed by Garrett and Sobel (2003) with respect to FEMA disaster aid in the US.

As outlined above, the current system of governmental intervention in Austria showed some weaknesses that might be overcome by the introduction of a system of risk transfer pillared by private insurers, reinsurance, and governmental stop-loss coverage. Therefore, premiums which are commensurate with the risk should be charged for hazard-prone property in order to overcome the phenomenon of adverse selection, including the offer of an incentives to invest into mitigation measures. These mitigation measures should include local structural protection since it had been shown that such measures are cost-efficient with respect to the minimisation of losses (e.g., Holub and Fuchs, 2008).

A possible approach of how disaster insurance or mountain hazards could be organised is presented schematically in Fig. 4. Taking the 1 in 150 year event as design event and according to studies published by Fuchs et al. (2004) and Keiler (2004), approximately $50 \%$ of all buildings in the Eastern Alps are located outside endangered areas. The residual number of buildings is located inside the red hazard zone $(5 \%)$, the yellow hazard zone $(25 \%)$ and the directly affected 10-m buffers (each buffer approximately 10\%). With increasing distance to the area affected by the hazardous process, the impact in terms of pressure or deposition height is decreasing. Hence, the property exposed is successively less susceptible to losses. Consequently, the premium rate to be levied by the insurance companies could be stepped according to such impact reductions based on defined reoccurrence intervals emerging from design events. The risk premium is further differentiated according to whether or not local protection measures had been implemented, which will create incentives to individuals and business entities to behave riskaware. If insurance against natural hazards is not compulsory, premiums being charged might be stepped according to suggestions (1a) and (1b). Assuming an average value of approximately $300000 €$ for a building located on a torrent fan in Austria (Fuchs et al., 2007a), the annual premium rate within the red hazard zone would amount to $2100 €$ without and $1050 €$ with local structural protection, probably in addition to a certain excess of a retention applicable for high-risk areas. In analogy, the annual premium rate within the yellow hazard zone would amount to $1050 €$ without and $480 €$ with local structural protection. Areas neither located in the red and yellow hazard zones nor in a directly attached buffer will be charged with $240 €$ and $150 €$ respectively. In addition, a suggestion for annual premium rates assuming a compulsory disaster insurance would result in $150 €$ per building affected without local protection (2a), and $60 €$ considering individual constructive mitigation measures (2b).

By establishing such a system of graduated premiums commensurate with the risk, the problem of adverse selection and moral hazard can be addressed and the loss compensation will become more equitable. To complement this system, information on hazard and risk at a specific location has to be communicated target-oriented to the stakeholders involved. In analogy to the Energy Performance Certificate providing home owners, tenants and buyers information on the energy efficiency of their property, a similar certificate approving the meeting of certain building code standards could encourage the adoption of cost-effective local mitigation structures. Such a certificate could in a subsequent step be valid as a basic requirement for getting insurance cover at reduced premium rates or presenting credit redemption agreements (e.g., Kleindorfer and Kunreuther, 1999). Furthermore, incentives might not only emerge from reduced premium rates but also from other benefits, e.g., reduced tax load on expenditures necessary to implement local structural protection.

\section{Awareness-building}

As a major part of the territory of Austria is located in mountain areas above $1000 \mathrm{~m}$ a.s.l. (approximately $36 \%$ of the territory; $50 \%$ of which is situated even higher than $1500 \mathrm{~m}$ a.s.l.), areas suitable for permanent settlements and economic activities are limited (Holub and Hübl, 2008). As a result, land development and building activities are concentrated on areas affected by natural hazards: in the mountainous regions of Austria, almost $50 \%$ of all buildings are potentially exposed to hazards including flooding, and almost $15 \%$ are considered to be at high risk (Fig. 4, Fuchs et al., 2004; Keiler, 2004).

Apart from land use regulations and risk transfer, information is a third pillar in order to create disaster-resilient communities. Hence, knowledge about the individual and the collective (cumulative) risk is an essential prerequisite for an adapted and anticipatory dealing with natural hazards to promote risk-decreasing behaviour. In order to meet this goal public attention has to be attracted, in analogy to the debate on climate change a trigger is often needed therefore (Egner, 2007). Generating this public attention creates the ability to communicate risk in a purposeful and targetoriented manner to different stakeholders affected. The perception of risk is different between experts and laypersons. 


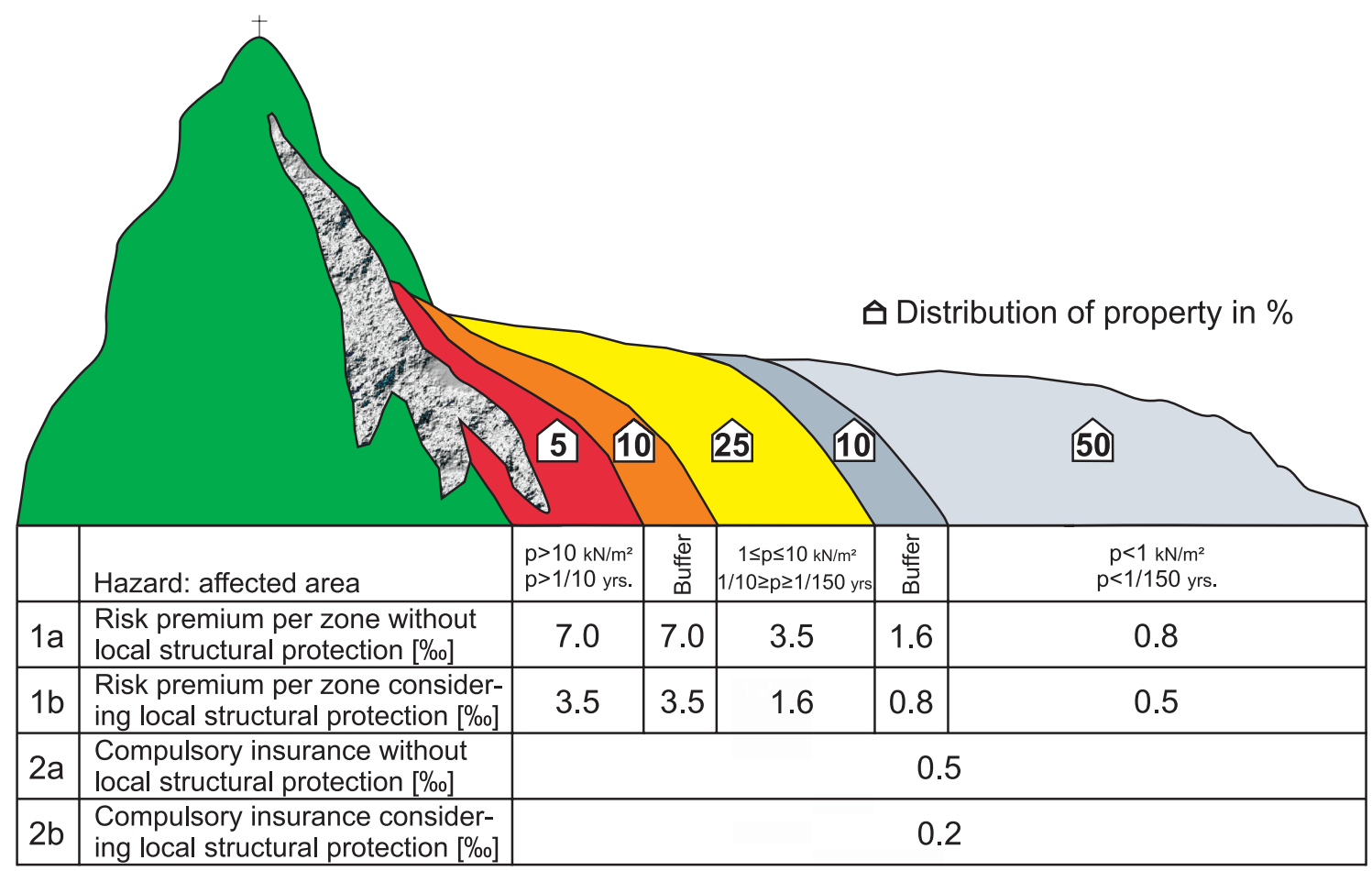

Fig. 4. Development of risk premiums if property insured is successively less exposed (modified from a sketch in Swiss Re, 1998, and adapted to mountain hazards). The percental distribution of property was taken from estimates outlined in Fuchs et al. (2005) and Keiler et al. (2006).

While some studies argue that considerable differences exist (e.g., Fischhoff et al., 1982; Lazo et al., 2000), often in dependence of whether or not affected people live in hazardprone areas (Siegrist and Gutscher, 2006), other studies conclude that there is little empirical evidence for such a proposition (Rowe and Wright, 2002). Information on risk is an essential step to enhance risk awareness and to create disasterresilient communities. Nevertheless, until now only little information has been available related to the necessary design and impact of such maps and how they may be most effectively created as tools for risk communication and decisionmaking. However, it is undoubted that with respect to hazard mitigation information on risk is an essential step to enhance risk awareness and to create disaster-resilient communities.

Hazard and risk maps, in which areas endangered by defined design events are depicted, provide one opportunity to communicate natural hazard risk and to inform about possible risk-reducing behaviour. Little information is available so far related to the necessary design and impact of such maps in order to serve as a risk communication tool (Serrhini et al., 2008; Fuchs et al., 2009). Covello et al. (1987) identified four components of risk communication: the message source, the message design, the delivery channel, and the target audience. This model depicts risk communication as linear, viewed as a means of transmitting technical information regarding risk from a known, intentional source (the experts) along designed channels, to specified recipients (the public affected). As outlined in Fuchs et al. (2009), experts draft and devise risk maps and associated documentation, and endusers (public authorities, people concerned, and laypersons) receive these maps as finished products regardless of whether or not they understand the message included. Hence, a feedback loop has to be established reversing the traditional way of communication, e.g., by a cyclical model which was proposed to integrate visual and cognitive perception by the receiver (Serrhini et al., 2008). However, there might still remain a gap between understanding and persuasion at the receivers side (Bell and Tobin, 2007), in particular with respect to the 1 in 150 years design event providing the basis for hazard maps in Austria.

Furthermore, hazard maps are not yet fully available for the entire area of Austria endangered by natural hazards since a nation-wide coverage is only expected to be implemented with respect to the European Flood Risk Directive over the next years (Commission of the European Communities, 2007). Many stakeholders concerned (e.g., homeowners, insurance companies, banks granting credits, and decision makers) therefore do not have access to the respective information and thus are not fully aware of hazard and risk maps, and consequently do only take care of hazards if they do already have experienced losses recently. Related to the communicative purpose that hazard maps might evoke, an adopted and risk-sensitive behaviour is therefore limited so far in Austria. Consequently, access 
to alternative information sources is inevitable. One step towards enhanced information might be the web-based nationwide available risk zoning tool "HORA" which was developed by the Austrian Insurance Association in cooperation with the Federal Ministry of Agriculture, Forestry, Environment and Water Management ${ }^{1}$, as well as the Swiss pendant "Aquaprotect".

The extent of consequences resulting from natural hazard events is strongly influenced by the behaviour of the population in endangered areas and by the duties of local authorities with respect to legal implementation. Since the state of information related to hazard exposure seems to be not sufficient so far in Austria, in particular non-technical mitigation measures neither are optimally nor efficiently adjusted to the possible consequences of hazardous events, and citizens very often even are not aware of their own exposure. Moreover, the subjective feeling of safety is strongly related to the hazard perception and awareness of affected people, and usually decreases with decreasing information on recent events. These patterns are overlain by the increasing demand for zero risk emerging in recent years, accompanied by an increasingly less willingness to invest private money for the mitigation of hazardous events, and the search for a culprit in case of a damaging event associated with losses.

If the increasing demand for a higher degree of protection is put forward the design and implementation of mitigation strategies not only has to focus on values currently being at risk. In addition, possible future system states have to be considered such as changes in the process behaviour leading to altered design events or an increase in exposed values (Keiler et al., 2006; Fuchs and Keiler, 2008). Furthermore, increasingly more attention has to be paid to possible system failures, and maintenance of protection structures becomes progressively more important due to the limited lifetime of such structures. Particularly with respect to the latter, the culture of oblivion outlined above appears to be a key element to the perceived decrease of public natural hazards' awareness. Since even structures designed for the 1 in 150 years flood are expected to fail the generation of information on risk organised as a dialogue-oriented process embedded in a participatory framework that allows the constructive and open engagement and integration of various stakeholders (experts, decision-makers and well as representatives of the local population) is preferable, including specific information requirements of citizens and relying on local expertise in the risk assessment process.

Complementary to these needs, particular attention has to be focused on local structural protection measures that provide a considerable and effective reduction of vulnerability directly at the endangered objects (Holub and Hübl, 2008). Previous experiences with losses due to natural

\footnotetext{
${ }^{1}$ http://gis.lebensministerium.at/eHORA

${ }^{2}$ http://umweltzustand.admin.ch/ubst.php?reset_session\ \&initialState=aquaprotect $\backslash \&$ lang=de
}

hazards and corresponding negative emotions expressed by affected people seem to be motivating for citizens to show damage mitigation behaviour (Kreibich et al., 2005; Siegrist and Gutscher, 2006). Contrariwise, a substantial number of people suffering severe losses due to natural hazards did not intend to invest private money in mitigation measures. Hence, experiencing strongly negative emotions seems to be a necessary but not in all cases sufficient condition for the implementation of local structural protection.

However, with respect to the effectiveness and efficiency, recent experiences with local structural protection suggested a considerable decrease in vulnerability (Fuchs et al., 2007a; Holub and Fuchs, 2008), hence they are an indispensable element of the natural hazard management. This is also mirrored by the current Austrian legal situation, according to the stipulated self-responsibility of citizens affected parties have to primarily compensate their losses themselves. Only in legally specified exceptions, these losses can be transferred to third parties.

To conclude, the vulnerability of buildings can be reduced significantly by local structural protection measures. Therefore, people have to be motivated to take preventive actions. An important prerequisite for implementing local structural protection is the conviction to be able to minimise personal risk and losses effectively by these measures. Hence, people must be aware of their risks, which is related to information, communication and good governance.

In order to achieve these goals, several strategies are conceivable to encourage the implementation of local structural protection by raising the risk awareness and personal responsibility of affected citizens:

1. By regularly and continuous information, coping capacities of people affected can be enhanced and thus, the personal responsibility and sensitisation towards natural hazards, risk and mitigation measures can be increased.

2. Specialised consulting for people affected with respect to prevention and local structural protection, including information about construction and maintenance costs of local structural measures, as well as the average height of reconstruction costs resulting from natural hazard damages in private households. Furthermore, these costs should be related to common loss adjustment and compensations paid out from insurers and the Austrian disaster fund.

3. Specialised consulting for homeowners, land use planners, and architects with respect to possibilities of prevention and local structural protection.

4. Specialised information and consulting following natural hazard events with respect to resistant construction design and materials.

Following these suggestions, the potential of preventive measures - currently mostly unused - which partly result from 
a lack of information and subsequently underdeveloped risk awareness, could be increased. This would consequently result in a decrease of losses due to natural hazards and public expenditures for loss adjustment.

\section{Conclusions}

Creating disaster-resilient communities is pillared by land use regulations, risk transfer, and information. In the previous sections, the legal framework of spatial planning has been discussed. It has been addressed that due to climate change processes, the hazard potential is subject to temporal changes, which are not yet fully acknowledged by the current spatial planning legislation in Austria due to the relatively long time interval of spatial planning activities. Furthermore, modifications in land use regulations are restricted to a minimum to ensure the required stability of the law. By exploiting all options already provided by the legislation on different administrative levels, due diligence as an obligation resulting in limitations of utilisation and culminating in prohibitions executed should be enforced. Thereby, land use regulations should include the prescription of local structural protection in order to create more disaster-resilient communities.

Disaster resilience is directly connected to risk transfer mechanisms. However, these risk transfer options should be based on economic incentives of risk-minimising behaviour. Hence, the current system of governmental aids due to the disaster fund act should be adjusted, and supplemented by a system of (mandatory) extension for property insurers in Austria by a natural hazard package. This insurance should be based on basic premiums charged commensurate with the risk in order to avoid adverse selection. Furthermore, individual precaution measures undertaken, such as the implementation of local structural protection, should result in a general insurability of buildings if natural hazard insurance is not organised compulsory, or in a considerable reduction of premiums (independently from whether or not this is in line with insurers' business principles).

To complement such incentives information on hazard and risk for a specific location has to be delivered target-oriented to any stakeholder involved. The consequences resulting from mountain hazards are strongly related to the behaviour of the population in endangered areas, and the behaviour is closely connected to the amount of information accessible. Apart from making use of innovative communication channels and adopted information strategies, the overall policy to inform people due to good governance principles has to be strengthened.

Mitigating mountain hazards is based on the need for a sound, precautionary and sustainable dealing with natural hazard phenomena, taking into consideration both, the processes and the values at risk. In order to minimise losses, different preventive measures exist that can be classified in permanent and temporal measures on the one hand, and structural measures as well as organisational measures (i.e., a governmental framework of spatial planning and appropriate legislation) on the other hand. These different measures ideally complement each other, whereby a focus on structural measures in the starting zones of hazard processes and land use planning activities in the run-out zones is detectable. With respect to the idea of integral risk management, the interaction between prevention and precaution has to be highlighted, and respective incentives for loss-reducing actions on the local level should be provided in order to reduce the vulnerability to natural hazards in Austria (Fuchs et al., 2007a; Fuchs, 2009). However, until now the performance of local structural measures often is neglected or even ignored following the axiom that such solutions cannot be effective. Local structural measures can be classified in various ways, i.e., according to the applicability for protection against the hazard process, the location with respect to the protected object, as well as the type of construction and material used; a further differentiation is possible whether the local structure is of permanent or temporary use (Holub and Hübl, 2008). The interaction between the legal framework, the possibilities of risk transfer, and raising awareness is essential for efficient disaster risk reduction and contributes to the concept of resilience as part of proactive adaptation. Coping strategies have to be adjusted to these premises, and in particular the implementation of local protection measures has to be strengthened legally, institutionally, and economically.

Acknowledgements. This work was supported by a research grant from the Austrian Science Fund (grant number L535-N10). The authors kindly acknowledge the insightful comments of T. Hlatky and another anonymous referee on an earlier version of the manuscript.

Edited by: T. Glade

Reviewed by: T. Hlatky and another anonymous referee

\section{References}

Amt der Oberösterreichischen Landesregierung: Landesgesetz vom 6. Oktober 1993 über die Raumordnung im Land Oberösterreich, LGB1. 115/2005, 2004.

Amt der Salzburger Landesregierung: Salzburger Raumordnungsgesetz 1998, LGB1. 44/1998, i.d.F. LGB1. 65/2004, 2004.

Amt der Tiroler Landesregierung: 27. Kundmachung der Landesregierung vom 21. Februar 2006 über die Wiederverlautbarung des Tiroler Raumordnungsgesetzes 2001, LGB1. 27/2006, 2006.

Amt der Vorarlberger Landesregierung: Verordnung der Landesregierung über die Neukundmachung des Raumplanungsgesetzes, LGB1. 39/1996, 1996. 
Bell, H. and Tobin, G.: Efficient and effective? The 100-year flood in the communication and perception of flood risk, Environmental Hazards, 7(4), 302-311, 2007.

CIPRA [International Commission for the Protection of the Alps]: Protokoll Bodenschutz, available at: http://www.cipra.org/de/alpenkonvention/ die-alpenkonvention-ein-alpenweit-gueltiges-vertragswerk/ resolveuid/9cb6dd101da42e0539ef54dd30dadb92, (last access: 31 October 2008), 1998.

Commission of the European Communities: Directive 2007/60/EC of the European Parliament and of the Council of 23 October 2007 on the assessment and management of flood risks, available at: http://eur-lex.europa.eu/LexUriServ/LexUriServ.do?uri=OJ: L:2007:288:0027:0034:EN:PDF, (last access: 31 October 2008), 2007.

Covello, V., Winterfeldt, D., and Slovic, P.: Communicating scientific information about health and environmental risk: Problems and opportunities from a social and behavioural perspective, in: Risk communication, edited by: Davies, J., Covello, V., and Allen, F., The Conservation Foundation, Washington, 109-134, 1987.

Cutter, S.: Vulnerability to environmental hazards, Prog. Hum. Geog., 20(4), 529-539, 1996.

Cutter, S., Boruff, B., and Shirley, W.: Social vulnerability to environmental hazards, Soc. Sci. Quart., 84(2), 242-261, 2003.

Egner, H.: Überraschender Zufall oder gelungene wissenschaftliche Kommunikation: Wie kam der Klimawandel in die aktuelle Debatte?, Gaia, 16(4), 250-254, 2007.

Fischhoff, B., Slovic, P., and Lichtenstein, S.: Lay foibles and expert fables in judgments about risk, The American Statistician, 36(3, Part 2), 240-255, 1982.

Froot, K. A.: The evolving market for catastrophic event risk, in: Risk management, edited by: Figlewski, S. and Levich, R., Dordrecht, Kluwer Academic Publishers, 37-65, 2002.

Fuchs, S., Bründl, M., and Stötter, J.: Development of avalanche risk between 1950 and 2000 in the Municipality of Davos, Switzerland, Nat. Hazards Earth Syst. Sci., 4, 263-275, 2004, http://www.nat-hazards-earth-syst-sci.net/4/263/2004/.

Fuchs, S., Keiler, M., Zischg, A., and Bründl, M.: The longterm development of avalanche risk in settlements considering the temporal variability of damage potential, Nat. Hazards Earth Syst. Sci., 5, 893-901, 2005,

http://www.nat-hazards-earth-syst-sci.net/5/893/2005/.

Fuchs, S. and McAlpin, M. C.: The net benefit of public expenditures on avalanche defence structures in the municipality of Davos, Switzerland, Nat. Hazards Earth Syst. Sci., 5, 319-330, 2005 , http://www.nat-hazards-earth-syst-sci.net/5/319/2005/.

Fuchs, S., Heiss, K., and Hübl, J.: Towards an empirical vulnerability function for use in debris flow risk assessment, Nat. Hazards Earth Syst. Sci., 7, 495-506, 2007a,

http://www.nat-hazards-earth-syst-sci.net/7/495/2007/.

Fuchs, S., Thöni, M., McAlpin, M., Gruber, U., and Bründl, M.: Avalanche hazard mitigation strategies assessed by cost effectiveness analyses and cost benefit analyses - Evidence from Davos, Switzerland, Nat. Hazards, 41(1), 113-129, 2007b.

Fuchs, S. and Keiler M.: Variability of natural hazard risk in the European Alps: Evidence from damage potential exposed to snow avalanches, in: Disaster management handbook, edited by:
Pinkowski, J., Taylor \& Francis, London, 267-279, 2008.

Fuchs, S.: Susceptibility versus resilience to mountain hazards in Austria - paradigms of vulnerability revisited, Nat. Hazards Earth Syst. Sci., 9, 337-352, 2009, http://www.nat-hazards-earth-syst-sci.net/9/337/2009/.

Fuchs, S., Dorner, W., Spachinger, K., Rochman, J., and Serrhini, K.: Flood risk map perception through experimental graphic semiology, in: Flood risk management, edited by: Samuels, P., Huntington, S., Allsop, W., and Harrop, J., Taylor \& Francis, London, 705-714, 2009.

Garrett, T. and Sobel R.: The political economy of FEMA disaster payments, Economic Inquiry, 41(3), 496-509, 2003.

Grothmann, T. and Reusswig. F.: People at risk of flooding: Why some residents take precautionary action while others do not, Nat. Hazards, 38(1-2), 101-120, 2006.

Gruber, M.: Alternative solutions for public and private catastrophe funding in Austria, Nat. Hazards Earth Syst. Sci., 8, 603-616, 2008,

http://www.nat-hazards-earth-syst-sci.net/8/603/2008/.

Hattenberger, D.: Naturgefahren und öffentliches Recht, in: Recht im Naturgefahrenmanagement, edited by: Fuchs, S., Khakzadeh, L., and Weber, K., Studienverlag, Innsbruck, 67-91, 2006.

Holub, M. and Fuchs, S.: Benefits of local structural protection to mitigate torrent-related hazards, WIT Transactions on Information and Communication Technologies, 39, 401-411, 2008.

Holub, M. and Hübl, J.: Local protection against mountain hazards state of the art and future needs, Nat. Hazards Earth Syst. Sci., 8, 81-99, 2008, http://www.nat-hazards-earth-syst-sci.net/8/81/2008/.

Jaffee, D. and Russell, T.: Markets under stress: The case of extreme event insurance, in: Economics for an imperfect world, edited by: Arnott, R., Greenwald, B., Kanbur, R., and Nalebuff, B., MIT Press, Cambridge, 35-52, 2003.

Kanonier, A.: Raumplanungsrechtliche Regelungen als Teil des Naturgefahrenmanagements, in: Recht im Naturgefahrenmanagement, edited by: Fuchs, S., Khakzadeh, L., and Weber, K., Studienverlag, Innsbruck, 123-153, 2006.

Keiler, M.: Development of the damage potential resulting from avalanche risk in the period 1950-2000, case study Galtür, Nat. Hazards Earth Syst. Sci., 4, 249-256, 2004, http://www.nat-hazards-earth-syst-sci.net/4/249/2004/.

Keiler, M., Sailer, R., Jörg, P., Weber, C., Fuchs, S., Zischg, A., and Sauermoser, S.: Avalanche risk assessment - a multi-temporal approach, results from Galtür, Austria, Nat. Hazards Earth Syst. Sci., 6, 637-651, 2006, http://www.nat-hazards-earth-syst-sci.net/6/637/2006/.

Kleindorfer, P. and Kunreuther, H.: The complementary roles of mitigation and insurance in managing catastrophic risks, Risk Anal., 19(4), 727-738, 1999.

Kreibich, H., Thieken, A. H., Petrow, Th., Müller, M., and Merz, B.: Flood loss reduction of private households due to building precautionary measures - lessons learned from the Elbe flood in August 2002, Nat. Hazards Earth Syst. Sci., 5, 117-126, 2005, http://www.nat-hazards-earth-syst-sci.net/5/117/2005/.

Kunreuther, H.: Strategies for dealing with large-scale and environmental risks, in: Frontiers in environmental economics, edited by: Folmer, H., Gabel, L., Gerking, S., and A. Rose, Edward Elgar, Cheltenham, 293-318, 2000. 
Kunreuther, H. and Pauly, M.: Neglecting disaster: Why don't people insure against large losses?, J. Risk Uncertainty, 28(1), 5-21, 2004.

Länger, E.: Der forsttechnische Dienst für Wildbach- und Lawinenverbauung in Österreich und seine Tätigkeit seit der Gründung im Jahre 1884, Dissertation an der Universität für Bodenkultur, Wien, 303 pp., 2003 (unpublished).

Lazo, J., Kinnell, J., and Fisher, A.: Expert and layperson perceptions of ecosystem risk, Risk Anal., 20(2), 179-193, 2000.

ÖROK [Österreichische Raumordnungskonferenz]: Präventiver Umgang mit Naturgefahren in der Raumordnung, Eigenverlag, Wien, 154 pp., 2005.

Österreichisch-Ungarische Monarchie: Gesetz vom 30. Juni 1884, betreffend Vorkehrungen zur unschädlichen Ableitung von Gebirgswässern, Reichsgesetzblatt für die im Reichsrath vertretenen Königreiche und Länder, Jg. 1870-1918 - Wien, Kaiserl.-königl. Hof- und Staatsdruckerei 1870-1918, 1884.

Prettenthaler, F., Hyll, W., and Vetters, N.: Ausgestaltung nationaler Risikotransfermechanismen: grundsätzliche Überlegungen, in: Extreme Wetterereignisse und ihre wirtschaftlichen Folgen, edited by: Steininger, K. W., Steinreiber, C., and Ritz, C., Springer, Berlin, 69-90, 2005.

Prettenthaler, F. and Vetters, N.: Finanzielle Bewältigung von Naturgefahren: Vorschläge zur Reform des österreichischen Modells, Intereg Working Paper Series 21-2005, 13 pp., 2005.

Raschky, P. and Weck-Hannemann, H.: Charity hazard - A real hazard to natural disaster insurance?, Environmental Hazards, 7(4), 321-329, 2007.

Raschky, P. A.: Institutions and the losses from natural disasters, Nat. Hazards Earth Syst. Sci., 8, 627-634, 2008, http://www.nat-hazards-earth-syst-sci.net/8/627/2008/.

Republik Österreich: Katastrophenfondsgesetz 1966, BGB1. 207/1966, 1966.

Republik Österreich: Forstgesetz 1975, BGB1. 440/1975, 1975.

Republik Österreich: Verordnung des Bundesministers für Landund Forstwirtschaft vom 30. Juli 1976 über die Gefahrenzonenpläne, BGB1. 436/1976, 1976.

Republik Österreich: Katastrophenfondsgesetz 1996, BGB1. 201/1996, 1996.

Romang, H., Kienholz, H., Kimmerle, R., and Böll, A.: Control structures, vulnerability, cost-effectiveness - A contribution to the management of risks from debris torrents, in: Debrisflow hazards mitigation: Mechanics, prediction, and assessment, edited by: Rickenmann, D. and Chen, C., Millpress Science Publishers, Rotterdam, 1303-1313, 2003.
Rowe, G. and Wright, G.: Differences in expert and lay judgments of risk: Myth or reality?, Risk Anal., 21(2), 341-356, 2002.

Schieferer, W.: Abwicklungsfragen im versicherungsrechtlichen Umfeld von Naturgefahren - Zukunftsperspektive der privaten Naturkatastrophen-Vorsorge nach dem Hochwasserereignis vom 23. August 2005, in: Recht im Naturgefahrenmanagement, edited by: Fuchs, S., Khakzadeh, L., and Weber, K., Studienverlag, Innsbruck, 115-122, 2006.

Serrhini, K., Rochman, J., Fuchs, S., Dorner, W., and Spachinger, K.: Sémiologie graphique expérimentale et cartographie du risque d'inondation, in: Atelier "Systèmes d'Information et de Décision pour l'Environnement", edited by: Pinet, F. and Miralles, A., Congrès Inforsid 2008, Cemagref, Clermont Ferrand and Montpellier, 2008.

Siegrist, M. and Gutscher, H.: Flooding risks: A comparison of lay people's perceptions and expert's assessments in Switzerland, Risk Analysis, 26(4), 971-979, 2006.

Swiss Re: Floods - An insurable risk?, Swiss Reinsurance Company, Zürich, 51 pp., 1998.

Ungern-Sternberg, T.: Efficient monopolies - The limits of competition in the European property insurance market, Oxford University Press, Oxford, 160 pp., 2004.

Varnes, D.: Landslide hazard zonation: A review of principles and practice, Paris, UNESCO, 60 pp., 1984.

Vetters, N. and Prettenthaler, F.: Extreme Wetterereignisse: Nationale Risikotransfersysteme im Vergleich, Universität Graz, 28 pp., 2004.

Weiß, R.: Versicherbarkeit von Naturkatastrophenschäden, in: Handbuch Naturkatastrophenrecht, edited by: Kerschner, F., Manz, Wien, 313-420, 2008.

Zischg, A., Fuchs, S., Keiler, M., and Stötter, J.: Temporal variability of damage potential on roads as a conceptual contribution towards a short-term avalanche risk simulation, Nat. Hazards Earth Syst. Sci., 5, 235-242, 2005, http://www.nat-hazards-earth-syst-sci.net/5/235/2005/.

Zischg, A., Fuchs, S., Keiler, M., and Meißl, G.: Modelling the system behaviour of wet snow avalanches using an expert system approach for risk management on high alpine traffic roads, Nat. Hazards Earth Syst. Sci., 5, 821-832, 2005, http://www.nat-hazards-earth-syst-sci.net/5/821/2005/. 